\title{
UNDERSTANDING ENGINEERING ETHICS
}

\author{
AbDi O. SHURIYe \\ Department of Science in Engineering, Faculty of Engineering, \\ International Islamic University Malaysia, \\ P.O. Box 10, 50728 Kuala Lumpur, Malaysia. \\ shuriye@iium.edu.my
}

\begin{abstract}
Engineering ethics aims to enhance engineer's ability to confront moral issues raised by engineering activities. It covers engineering as social experimentation, the engineer's responsibility for safety, and the rights of engineers. What constitutes engineering ethics is the underlining question of this research. Hence, the objective of the research is to systematically provide answers to the aforementioned question. The research also studies the scope and the origin of the subject matter. At the same time, the research highlights the significance of the subject from diverse perspectives; including Western and Islamic perspectives.
\end{abstract}

ABSTRAK: Etika kejuruteraan bertujuan meningkatkan keupayaan juruera menghadapi isu-isu moralyang timbul dari aktiviti-aktiviti kejuruteraan. Ia merangkumi kejuruteraan sebagai eksperimentasi sosial, tanggungjawab jurutera terhadap keselamatan dan hak-hak jurutera. Persoalan utama penyelidikan ini adalah apa yang merangkumi etika kejuruteraan. Penyelidikan ini juga mengkaji skop dan asal usul etika kejuruteraan. Kajian ini turut membincangkan subjek kajian dari pelbagai perspektif, Barat dan Islam.

KEYWORDS: engineering ethics; engineer; akhlaq; values; confidentiality; corruption; conflict of interest; whistle-blowing

\section{INTRODUCTION}

This research explores the functions of engineering ethics. The researcher employed a library-based evaluative method to arrive at comprehensive findings. The significance of this research is that it contributes to the better understanding of engineering ethics. The data of this research is mainly collected from the available resources. The study on engineering ethics is a timely exercise as engineers increasingly confront with ethical problems in their workplace. These ethical prdicaments and decision-making dilemmas include engineering confidentiality, corruption, conflict of interest, whistle-blowing and other related ethical impasses.

\section{ROOTS OF ETHICAL STUDIES}

In Islam the etymology and hermeneutics of akhlaq (Islamic ethics) are found in the Qur'an and in the hadith, whereas in the West ethics is rooted in philosophy. This positioning of ethics and moral studies is imperative here. It indicates that in Islam akhlaq is part or at least directly related to Godly principles, whereby in the West ethics and religion are two demarcate poles of the same intent.

For that reason the term akhlaq hermeneutically speaking should not be directly interpreted as ethics or morals. On balance, ethics in the Western sense of understanding is a set of principles of right conduct, it also refers to theories or systems of moral values, but 
IIUM Engineering Journal, Vol. 12, No. 5, 2011: Special Issue on Science and Ethics in Engineering

Shuriye

it does not refer to spiritual principle or Godly rewards in the hereafter, (al-Thawab fi alakhirah). Whilst, akhlaq in Islam has direct relations to spiritual standards of human behavior, attitude and character and its general sense of hermeneutics revolve around character, Islamic customs and Islamic way of life.

The Qur'anic constituents are Tawhid, Shari'ah and Akhlaq, the hadith covers the same. Prophet Muhammad was appointed and selected by Allah the Almighty as the final Prophet for mankind because he had a high level of Akhlaq, not because of any other factor or criterion. He was told by Allah: "And you are on an exalted standard of character" The Prophetic bears this a witness and said: "I have been sent down "only" to perfect good manners" (Qur'an, 68:4)

A Muslim faith without akhlaq is shaky and serves not religious values. The Prophet told us in an authentic hadith that: "The most perfect man of the believers (mu'minin) in their faith is that who has the best akhlaq among you" (Sahih al-Bukhari)

From the time of Prophet Ibrahim to Prophet Muhammad to the time of this author and his students, from the time of the Greek period of scientific development to the period of modern Western economic crisis ethics as a tool to measure human action remains relevant.

However, as many will agree with me, ethical studies are of diverse. In some aspects they evaluate and characterize the meaning of ethical terms and statements. Other part of ethical studies deal with how people actually behave. Most ethical studies however, are teleological in nature, promoting the idea that actions are moral, provided that they target moral goal. (Abdi O. Shuriye, 2006)

Ethics is related to rationality. Socrates (470-399 B.C.) started the pursuit of ethics is from rational perspective. Plato's (428-348 B.C.) approach is similar to that of his teacher, as the theory of reality became the bases for his ethical studies. The theory of forms described morality and ethics as the form or the idea of eternal and static structure. Morality, according to Plato, therefore, falls under these structures, and it becomes knowledge as moral people are wise, just, rational, courageous, moderate and harmonious with their soul. (Abdi O. Shuriye, 2006)

Ethicists refer to Aristotle (384-322 B.C.) as one who drew distinction between him and Plato as he based morality or human nature. Meeting the needs or achieving happiness, the ultimate goal for life, is the purpose of ethics for Aristotle. To achieve happiness, however, requires following some structured guidelines through reasoning, as a rational person adheres to some traits to maintain or achieve happiness. Epicureanism, an early school of moral philosophy, which was developed after the demise of Aristotle, is worth mentioning in this regard. Epicurus (341-270 B.C.) the founder of what later to be known as Epicureanism, believed that the highest good is to avoid pain and pursue pleasure. Another ethicist school of the same period, the Stoicism, advocated control of the emotions as the highest level of moral standards. (Abdi O. Shuriye, 2006).

After the emergence of Christianity however, the literature on ethics, methods and approaches of study took diverse directions. God became the ultimate reality in the mind of many ethicists and scholars formulated new methods and trends. As the purpose of life in Christianity is to rule the earth on moral grounds, and not merely attaining world pleasure, which is a religious message, St. Augustine (354-430 A.D) spearheaded the trend of Christian moral harmony. Other Christian theologians include Thomas Aquinas (12251274 A.D.). Aquinas moral theory was based upon natural law. He contended that the ultimate good of humans is spiritual union with God. Christians accept that ethical issues 
are part of larger scheme of revelation. Unlike the contemporary Western knowledge which places ethics under the studies of philosophy. (Abdi O. Shuriye, 2006)

It must be reiterated that the systematic study of values is what ethicists call ethics; it is the study of how to live decent, as such ethicists are concerned with how to determine standards. The two terms "ethics" and "morality" become imperative at this point. These terms are interchangeable in most cases. Morality deals with code of conduct. However, authorities of the subject argue that ethics refer to system of values, while, morality connotes righthood or wronghood. That indicates the fact that ethics is concerned with the systematic study of human values including the theories of conduct and focuses on moral dimensions of human life. (Abdi O. Shuriye, 2006)

Ethical studies also evaluate moral concepts and identify the significant of their approach. Utilitarian ethicists focus on maximizing human well being as a whole. Basic approaches of utilitarianism are Act-Utilitarianism which focuses on actions, not the rule, of the individual. John Stuart Mill (1806-1873) is considered one of the advocates of Act Utilitarianism, as we will illustrate it in the related chapters. (Abdi O. Shuriye, 2006)

Another approach is what ethicists term it as Rule-Utilitarianism which holds that moral rules are more imperative as the ethical rules will, in its general outlook, lead to the well being of all. Duty ethics is another moral theory; an idea that our duty to behave morally becomes obligatory upon us. Right ethics theory which advocates the contention that societies have moral rights and violating it is deemed unethical is another ethical theory related to. Both Right and Duty ethics theories do not take consequences of an action or overall good of the action, into considerations. Meanwhile virtue ethics theory outlines the idea of moral distinction, traits and character-fine, emphasizing on the personality. (Abdi O. Shuriye, 2006)

\section{ENGINEERING ETHICS}

In this section I shall attempt to put engineering ethics into clear perspective. Engineering ethics is a purpose of virtues and the ideals to the goal of creation of useful and safe technological products and services. (Abdi O. Shuriye and Ahmad Faris Ismail, 2011) It is also a shared moral values by engineers, without these common values it would be exceedingly intricate for engineers to agree on any one course of action in the workplace. (Abdi O. Shuriye and Ahmad Faris Ismail, 2011)

It must be said that engineering ethics covers the principles of moral reasoning and relates it to the engineer's professional life. Moreover, engineering ethics is the part of ethics related to the work of engineers, engineering studies, and engineering curriculum. In other words it acts as a moral guidance for engineers, as it enables engineers to critically understand and reflect the moral issues surrounding them. It further helps engineers to conceptualize ethical challenges. However, it must be said that, engineering ethics refers to a set of specific engineering problems. As it also refers to accepted codes and standards in various organized groups of engineering societies. (Abdi O. Shuriye and Ahmad Faris Ismail, 2011)

As far as its functionality is concerned, engineering ethics employs normative inquisitions, and through this normative inquest, moral directives and ethical rules are established. This reminds us that engineering ethics is the ability to implement awakened sense of integrating professional life and personal conviction to maintain moral autonomy and integrity. (Abdi O. Shuriye and Ahmad Faris Ismail, 2011) 
Engineering ethics is about moral rights of the engineers. The term moral rights refer to what is morally and ethically there for engineers. It also reflects the ability of an engineer to claim what is morally hers or his, what is under her or his control, and what action is morally acceptable. (Abdi O. Shuriye and Ahmad Faris Ismail, 2011)

On a related aspect, it must be observed that, engineering ethics is an appliance of descriptive investigation, it means, engineering ethics describes how engineers behave and what sorts of moral standards they claim to follow. If we understand engineering ethics this way we will be able to comprehend the attitude of engineers and what they do or have believed about moral rules. (Abdi O. Shuriye and Ahmad Faris Ismail, 2011)

Engineering ethics covers diverse spectrum of issues related to engineering work and engineering professions. These includes but for sure not limited to confidentiality, whistleblowing, conflict of interest and corruption. In engineering practices, confidentiality is the process of ensuring that information is accessible only to those authorized to have access to. Confidentiality, therefore, is the scheme of reality, that no facts, data, or information should be revealed without the prior consent of the client. (Abdi O. Shuriye and Ahmad Faris Ismail, 2011)

Engineering Corruption on the other hand is anything associated with illegitimate personal or organizational gain. Engineering bribery is a favour offered or given to an engineer in a position of trust in order to induce him/her to act dishonestly or against his/her profession. One must bear in mind that, engineering corruption is of broader spectrum than engineering bribery, and may encompass fraud and misuse of power. (Abdi O. Shuriye and Ahmad Faris Ismail, 2011)

Conflict of interest refers to a set of conditions in which professional judgment concerning a primary interest tends to be unduly influenced by a secondary or personal interest. (Krimsky, S. and Rothenberg, L.S., 2001) Thus, conflict of interest exists when an engineer has influence on official decisions where the outcome of that decision might affect the engineer's personal interest. (Warner, T. D. and Gluck, J. P., 2003) There are three types of conflict of interest; namely, actual, potential and appearance of conflict of interest. Actual or direct conflict of interest is any act that compromises objective engineering judgment. (Conflict of Interest Handbook, 2009) Potential conflict of interest on the other hand is a situation where an engineer befriends with a supplier, client or service provider. Although this situation does not necessarily constitute a conflict of interest, there is a potential that the engineer's judgment might conflict with the needs to maintain the friendship. (Conflict of Interest Handbook, 2009) Appearance conflict of interest occurs on commission based jobs. (Ackerley, N., Eyraud, J. and Mazzotta, M., 2007)

Whistle-blowing is a recent term in the hermeneutics of ethical studies. It connotes an act of engineer in disclosing unethical or illegal behaviour by an employer or supervisor by informing the public or higher management. It occurs when an insider reports alleged organizational misconduct to the public. Whistle-blowing consists of four essences; act of disclosure, topic, agent and recipient. As such, engineer is obliged to blow the whistle on acts or project which violates ethical, religious or universal values. Engineers also have the professional right to disclose any wrongdoing within their organizations and expect to see appropriate action taken. (Abdi O. Shuriye and Ahmad Faris Ismail, 2011)

In Islamic norms, whistle-blowing is associated with negative as well as positive aspects of human action. Instance of this is that an act of whistle-blowing by an engineer could be interpreted as backbiting (ghibah), spying on others (tajasus), rumour mongering 
or scandalous statements (fadhihah or fitnah). At the same time it could be seen as an advice (nasiha), enjoin good and forbidding bad (al-amr bi al-ma'rufi wa an-nahy 'an almunkar), arbitration (sulh or islah). (Abdi O. Shuriye and Ahmad Faris Ismail, 2011) So it will depend on how the engineer concern puts it, therefore, the act of blowing a whistle should be in line with the universal norms.

Engineering professional ethics refers to the moral rules that professionals should adhere to. Duties performed by engineers, for instance, are comparatively risky and could annihilate nations if ethical rules ignored. Professional duty requires extensive formal education, use of judgment and high level of skills with governing standard principles. (Abdi O. Shuriye, 2006)

Professional duty also comes with autonomy, knowledge, recognition and licensing or certification from a recognized bodies and authorities. Construction sector, road and rail networks, transportation systems, and environment, are only some areas that unethical professionals could contaminate it. Exposing of deadly virus by an immoral physician could cause the death of millions before it could be contained. For this raison d'être, profession requires deontological oath which makes the professional to be duty-based. Professional organizations have made the oath mandatory to set a moral stage. Nonetheless, poor services and selfish personal interest, unfortunately remains, intact. (Abdi O. Shuriye, 2006)

\section{CONCLUSION}

Finally it must be said that engineering ethics is concerned with professionalism, itqan (perfection), ihsan (goodness in production), taqwa (God consciousness at work) and 'adalah (justice) not only by Muslim engineers but to certain scale in universal stage. Engineering ethics is the study of moral issues and decisions confronting the engineer in the workplace. As a matter of fact, amoralists, axiologists, deontologist, sensationalists, metaethicists, synteresists, and utilitarians are all ethical schools of thought and doctrines investigate ethical issues. This itself connotes the imperativeness of engineering ethics. A world without ethics is a world devoid of guiding principles. Ethicists have taken diverse positions in their approach but concur on the fact that ethics is an integral part of an engineer's professional life. Engineering ethics is also an imperative tool to measure the attitude, and the work-ethics of an engineer.

\section{REFERENCES}

[1] Al-Qua' an Al-Karim.

[2] Abdi O. Shuriye and A. F. Ismail, Qur'anic Values and Engineering Studies: Approaches and Methods in the Process of Islamizing Engineering Curriculum. Pearson International, Kuala Lumpur, pp. 2-4, 21-23, 2011

[3] Abdi O. Shuriye, Islamic Ethical Values on Bioengineering Practices: Issues in Genetic Engineering. Research Management Centre, IIUM, pp. xiv- xvi, 2006.

[4] S. Krimsky and L.S. Rothenberg, "Conflict of interest Policies in Science and Medical Journals: Editorial practices and Author disclosures." Science and Engineering Ethics, Vol.7, pp. 205-218, 2001.

[5] T. D. Warner and J. P. Gluck, "What do we really know about conflicts of interest in biomedical research?" Psychopharmacology, Vol.171, pp.36-46, 2003.

[6] N. Ackerley, J. Eyraud, and M. Mazzotta, "Measuring Conflict of Interest and Expertise on FDA advisory committees (Task Order NO. 14 Contract NO. 223-03-8500)." Eastern Research Group, Inc., p.55, 2007 
IIUM Engineering Journal, Vol. 12, No. 5, 2011: Special Issue on Science and Ethics in Engineering

[7] Conflict of Interest Handbook, the California State University, p. 14, 2009.

[8] C.B. Fleddermenn, "Engineering Ethics." Prentice Hall, p. 881999.

[9] Mohamed Bin Ismail al-Bukhari, Sahih al-Bukhari, Dar al-Qalam, Beirut, in al-Adab alIfrad, 1987.

[10] Abi Da'ud, Sulayman ibn Ash- 'Ashath As-Sajastani. Sunan Abi Da'ud, Beirut, Dar al-Kutub al-Ilmiyah, in bab al-fadail, 2001.

[11] Abdul Haq Ansari, Islamic Ethics: Concept and prospect, In the American Journal of Social Sciences, vol. 6, no. 1, p. 87, 1989.

[12] Fazlur Rahman, Law and Ethics In Islam, in Ethics in Islam ed by Richard G. Hovannisian, Undena Publications, California, p. 7, 1985.

[13] Majid Fakhry, Ethical Theories in Islam, E.J. Brill, Leiden, 1990.

[14] Abdullah Omar Naseef, The Role of Faith and Islamic Ethics in the Teaching of Natural and Applied Sciences, in The Islamic Quarterly: a Review of Islamic Culture, vol. 26, no. 3, p. 135, 1982.

[15] Charles E Harris et al, Engineering Ethics, England, Wadsworth Publishing Company, p.27, 1995.

[16] Martin, M. W. and Schinzinger, R., Ethics in Engineering, McGraw-Hill, USA, p. 34, 1991. 